\title{
Rhizobium radiobacter - A rare organism causing central line-associated bloodstream infection in a preterm neonate
}

\author{
Vishal Dwarkaprasad Bhansali ${ }^{1}$, Shilpa Umesh Kalane ${ }^{2}$, Hemant Mandke ${ }^{3}$, Geethu Joe ${ }^{4}$ \\ From ${ }^{1}$ Fellow Neonatology, Department of Pediatrics, ${ }^{2}\left(D N B\right.$ Neo), Neonatologist, Department of Neonatology, ${ }^{3}$ Dch, MD Paediatrics, \\ Department of Pediatricis, ${ }^{4} \mathrm{MD}$ Microbiology, Department of Microbiology, Deenanath Mangeshkar Hospital and Research Centre, Pune, \\ Maharashtra, India
}

\begin{abstract}
Rhizobium radiobacter is an opportunistic human pathogen. Infections due to $R$. radiobacter are strongly related to the presence of foreign plastic materials and effective treatment often requires removal of the device. We report a case of $R$. radiobacter bloodstream infection associated with a central venous catheter, which was easily controlled by antimicrobial treatment and removal of the catheter. To the best of our knowledge, this is the first case report of $R$. radiobacter as a cause of central line-associated bloodstream infection in a preterm neonate.
\end{abstract}

Key words: Central line, Central line-associated bloodstream infection, Neonate, Rhizobium radiobacter, Sepsis

$\mathrm{N}$ osocomial sepsis in the neonatal intensive care unit (NICU), often by drug-resistant strains, is a major cause of mortality, prolonged hospitalization, and increased hospitalization costs [1]. A central line-associated bloodstream infection (CLABSI) contributes considerably to nosocomial sepsis in neonatal units. Over the past decade, CLABSI incidence in India has been varying from $0.2 \%$ to $27 \%$, with the rate of $0.5-47$ per 1000 catheter days in various studies [2]. Of all the organisms reported in literature, Rhizobium radiobacter appears to be the rare cause of CLABSI in pediatric population. However, CLABSI due to $R$. radiobacter has not yet been described. Hereby, we report the first case report of CLABSI in a preterm neonate caused by $R$. radiobacter.

\section{CASE REPORT}

A male baby, born at 34 weeks of gestation to a primigravida mother by cesarean section (meconium stained liquor) with antenatal sonography suggestive of jejunal obstruction, was referred to NICU for further management. On admission, the baby was stable with no obvious dysmorphic features. Abdominal radiograph at $6 \mathrm{~h}$ of life was suggestive of midgut obstruction. Exploratory laparotomy was performed on day 2 of life. Intraoperative findings were suggestive of jejunal atresia.

\section{Access this article online}

Received - 05 August 2020

Initial Review - 29 August 2020

Accepted - 30 October 2020

DOI: $10.32677 / \mathrm{IJCH} .2020 . v 07.110 .006$
Jejunoplasty was performed. Immediate post-operative course was uneventful. A peripherally inserted central catheter (PICC) was secured on the day of operation and total parenteral nutrition (TPN) was started. The baby was kept nil per oral for 20 days and was supported with TPN as per the unit protocol.

On day 21, the baby appeared off colored, lethargic, and had an apnea episode requiring stimulation. The baby was put on continuous positive airway pressure support. Septic screen was sent and third line intravenous (IV) antibiotics (meropenem and colistin) were started. Two sets of blood culture (using BACTECautomated blood culture system) were obtained before starting antibiotics. The first one was collected from the peripheral vein through a separate venipuncture site, whereas the second one was collected from the PICC through the new connector after discarding the old connector. Septic screen results were positive (hemoglobin $-10.1 \mathrm{~g} / \mathrm{dL}$, total leukocyte counts $17,340 / \mathrm{uL}$, neutrophils $55.8 \%$, lymphocytes $31.7 \%$, platelets $197,000 / \mathrm{mm}^{3}$, C-reactive protein was $75 \mathrm{mg} / \mathrm{dL}$, serum sodium $129 \mathrm{meq} / \mathrm{L}$, and potassium $3.8 \mathrm{meq} / \mathrm{L}$ ). Lumbar puncture done on the same day was normal.

Blood for aerobic culture was inoculated into blood culture pediatric bottle (Becton Dickinson) and was loaded into the BACTEC machine which flagged positive in 2 days showing thin Gram-negative, non-fermenting bacilli. The isolate was identified as $R$. radiobacter with $99 \%$ confidence (Fig. 1a-c). Further, manual biochemical tests were carried out to confirm the identification. The isolate was oxidase positive, motile, strongly urease positive,

Correspondence to: Dr. Vishal Dwarkaprasad Bhansali, NICU, $3^{\text {rd }}$ Floor, Super Specialty Building, Deenanath Mangeshkar Hospital, Pune - 411 004, Maharashtra, India. E-mail: vishbhansali24@gmail.com

(C) 2020 Creative Commons Attribution-NonCommercial 4.0 International License (CC BY-NC-ND 4.0). 
and was able to hydrolyze esculin. The isolate was susceptible to carbapenems, resistant to aminoglycosides and fluoroquinolones, however, exhibited variable susceptibility to cephalosporins. After obtaining the sensitivity report, antibiotics were stepped down. Appropriate IV antibiotics were given for total 14 days. The baby showed clinical improvement within $24 \mathrm{~h}$ of starting antibiotics and was symptom free in $48 \mathrm{~h}$. Neurosonography was normal. Feeds were initiated on day 25 of life. The baby tolerated feeds well and was discharged home on day 44 of life. Baby weighed $2200 \mathrm{~g}$ at discharge. At present, the baby is 3 months of age and has developmental milestones appropriate for the age.

\section{DISCUSSION}

Hospital-acquired infections (HAIs) are among the most common complications of hospital care, leading to high morbidity and mortality [1]. Insertion of central line, a common procedure in critical care settings, is one of the common causes of HAI [1]. The common organisms associated with CLABSI are Staphylococcus aureus and coagulase-negative staphylococci, Klebsiella spp., Acinetobacter baumannii, Escherichia coli, and Pseudomonas aeruginosa. Rare organisms such as Enterobacter spp., Serratia marcescens, Malassezia furfur, or Candida parapsilosis have also been reported in literature [3].

Strains of Rhizobium species (formerly Agrobacterium) are aerobic, motile, oxidase-positive, and non-spore-forming Gram-negative bacilli [4]. Among the species of Rhizobium, R. radiobacter is most commonly causing disease in humans. It has been recognized as an opportunistic human pathogen and has been associated with systemic diseases such as - peritonitis, urinary tract infection, myositis, and infection of indwelling intravascular devices in immunocompromised patients. $R$. radiobacter as a cause of neonatal sepsis has been reported in the literature [5-8]. The summary of the reports is depicted in Table 1. To the best of our knowledge, ours is the first case report of $R$. radiobacter causing CLABSI.

The day of the presentation varied in all cases. Fever followed by lethargy was observed to be a common presentation [5-7]. In our case, the baby was lethargic and off-colored at the time of presentation. Prematurity was a common risk factor emphasizing the preference of this bacteria for immunocompromised $[9,10,11,12]$. In the index case, the PICC was seen as an additional and important risk factor. The PICC as the cause for $R$. radiobacter sepsis was established by the documentation of its growth in the blood culture

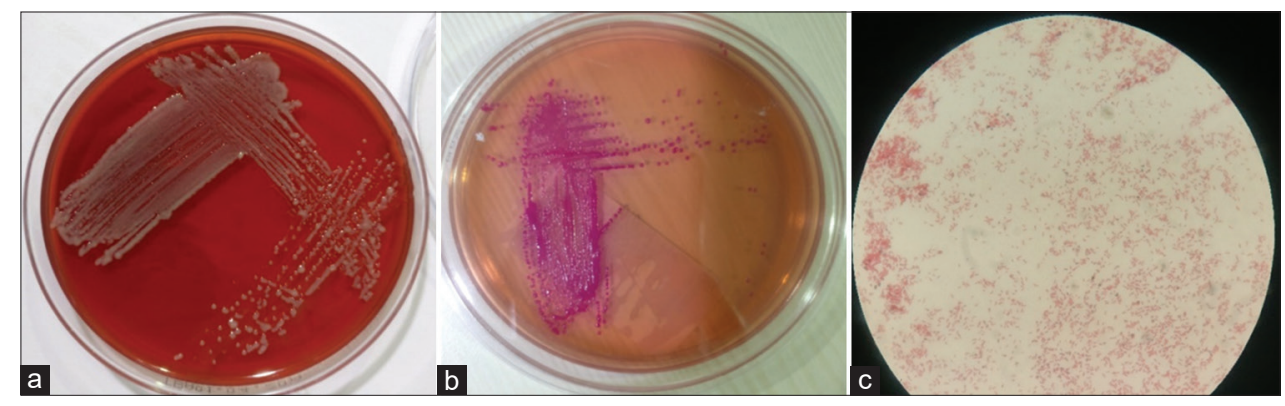

Figure 1: (a) Tenacious colonies of Rhizobium radiobacter in isolates from blood specimens from our patient. Colonies with growth of 1 mm in diameter, which were convex, smooth, and shining, grew on blood agar. (b) On MacConkey agar non-lactose fermenting colonies which on extended incubation (after completion of $48 \mathrm{~h}$ ) turned wet looking mucoid pink. (c) A colony smear prepared on Gram stain from the plates showed thin Gram-negative bacilli with stubby ends

Table 1: Summary of case reports on Rhizobium radiobacter sepsis in neonates

\begin{tabular}{|c|c|c|c|c|c|c|}
\hline $\begin{array}{l}\text { Cases } \\
\text { No. }\end{array}$ & Case report & Clinical features & $\begin{array}{l}\text { Day of presentation } \\
\text { after birth }\end{array}$ & Risk factors & $\begin{array}{l}\text { Sensitivity report } \\
\text { Sensitive (S) } \\
\text { Resistant (R) }\end{array}$ & Outcome \\
\hline 1. & $\begin{array}{l}\text { Kaselitz } \\
\text { et al. [7] }\end{array}$ & $\begin{array}{l}\text { Apnea, Cyanosis, } \\
\text { bradycardia }\end{array}$ & Day 1 & $\begin{array}{l}\text { Home delivery, herbal } \\
\text { supplements }\end{array}$ & $\begin{array}{l}\text { Aminoglycosides (S) } \\
\text { Carbapenems }(\mathrm{S}) \\
\text { Fluroquinolones }(\mathrm{S})\end{array}$ & $\begin{array}{l}\text { Discharged at } 14 \\
\text { days of life. }\end{array}$ \\
\hline 2. & $\begin{array}{l}\text { Khan } \\
\text { et al. [6] }\end{array}$ & $\begin{array}{l}\text { Fever, abdomen } \\
\text { distension }\end{array}$ & Day 115 & Preterm, repeated sepsis & $\begin{array}{l}\text { Aminoglycosides (S) } \\
\text { Carbapenem (S) } \\
\text { Fluroquinolones }(\mathrm{S})\end{array}$ & $\begin{array}{l}\text { Died due to } \\
\text { prematurity-related } \\
\text { complication. }\end{array}$ \\
\hline 3. & $\begin{array}{l}\text { Tiwari and } \\
\text { Beriha [4] }\end{array}$ & $\begin{array}{l}\text { Fever, lethargy, } \\
\text { refusal to feed, } \\
\text { tachypnea }\end{array}$ & Day 4 & No risk factor & $\begin{array}{l}\text { Aminoglycosides (S) } \\
\text { Cephalosporin (S) } \\
\text { Carbapenems (S) } \\
\text { Fluoroquinolones (S) }\end{array}$ & $\begin{array}{l}\text { Discharged at } 14 \\
\text { days of life }\end{array}$ \\
\hline 4. & $\begin{array}{l}\text { Surpam } \\
\text { et al. [5] }\end{array}$ & $\begin{array}{l}\text { Fever, lethargy, } \\
\text { refusal to feed, } \\
\text { tachypnoea }\end{array}$ & Day 2 & $\begin{array}{l}\text { Preterm, PPROM }>24 \mathrm{~h} \text {, } \\
\text { foul-smelling liquor }\end{array}$ & $\begin{array}{l}\text { Aminoglycosides (R) } \\
\text { Carbapenems (S) } \\
\text { Fluroquinolones (S) }\end{array}$ & $\begin{array}{l}\text { Discharged at } 20 \\
\text { days of life }\end{array}$ \\
\hline 5. & Our case & $\begin{array}{l}\text { Off colored, lethargy, } \\
\text { apnea }\end{array}$ & Day 21 & $\begin{array}{l}\text { Preterm, peripherally } \\
\text { inserted central catheter, } \\
\text { total parenteral nutrition }\end{array}$ & $\begin{array}{l}\text { Aminoglycosides (R) } \\
\text { Carbapenems (S) } \\
\text { Fluroquinolones (R) }\end{array}$ & $\begin{array}{l}\text { Discharged at } 44 \\
\text { days of life }\end{array}$ \\
\hline
\end{tabular}


sent in pair (blood collected from PICC and the peripheral vein). This was a proven case of $R$. radiobacter CLABSI. Although all previous case reports showed uniform sensitivity of the bacteria to the carbapenems, the sensitivity pattern for aminoglycosides and fluoroquinolones varied between centers. However, the overall prognosis remains excellent.

A strong clinical suspicion of CLABSI should be kept in sick preterm neonates with central venous catheters in situ [13]. Paired blood cultures (from the central line and peripheral vein) should be sent to confirm the diagnosis of CLABSI. Prognosis of $R$. radiobacter CLABSI if diagnosed early and treated promptly is excellent.

\section{CONCLUSION}

We report a case of invasive $R$. radiobacter infection in a newborn infant with a history of central venous catheterization. Although having a low virulence, it is highly susceptible to many antibiotics. Usually, appropriate antimicrobial therapy and removal of foreign devices are necessary to control infection.

\section{REFERENCES}

1. Allegranzi B, Nejad SB, Combescure C, Graafmans W, Attar H, Donaldson L, et al. Burden of endemic health-care-associated infection in developing countries: Systematic review and meta-analysis. Lancet 2011;377:228-41.

2. Sarala KS. Clinico-epidemiological profile of central line-associated blood stream infections and associated morbidities among patients in a tertiary care hospital, Bangalore. Natl J Community Med 2017;8:559-63.

3. Ramasubramanian V, Iyer V, Sewlikar S, Desai A. Epidemiology of healthcare acquired infection-an Indian perspective on surgical site infection and catheter related blood stream infection. Indian J Basic Appl Med Res 2014;3:46-63.

4. Young JM, Kuykendall LD, Martinez-Romero E, Kerr A, Sawada H. Classification and nomenclature of Agrobacterium and Rhizobium. Int J Syst Evol Microbiol 2003;53:1689-95.

5. Tiwari S, Beriha SS. Primary bacteremia caused by Rhizobium radiobacter in neonate: A rare case report. J Clin Diagn Res 2015;9:DD01-2.

6. Surpam R, Gawande R, Munde B, Kolhe V. Rhizobium radiobacter bacteremia in a neonate-a case report. Paripex Indian J Res 2020;8:98-9.

7. Khan S, Al-Sweih N, Othman AH, Dhar R. Bacteremia caused by Rhizobium radiobacter in a preterm neonate. Indian J Pediatr 2014;81:191-2.

8. Kaselitz TB, Hariadi NI, LiPuma JJ, Weinberg JB. Rhizobium radiobacter bacteremia in a neonate. Infection 2012;40:437-9.

9. Christakis GB, Alexaki P, Alivizatos AS, Chalkiopoulou I, Athanasiou AE, Zarkadis IK. Primary bacteraemia caused by Rhizobium radiobacter in a patient with solid tumors. J Med Microbiol 2006;55:1453-6.

10. Mantadakis E, Kondi A, Christidou A, Kalmanti M. Agrobacterium radiobacter bacteremia in a child with acute lymphoblastic leukemia. World J Pediatr 2010;6:181-4.

11. Amaya RA, Edwards MS. Agrobacterium radiobacter bacteremia in pediatric patients: Case report and review. Pediatr Infect Dis J 2003;22:183-6.

12. Paphitou NI, Rolston KV. Catheter-related bacteremia caused by Agrobacterium radiobacter in a cancer patient: Case report and literature review. Infection 2003;31:421-4.

13. Sood S, Nerurkar V, Malvankar S. Catheter associated bloodstream infection caused by $R$. radiobacter. Indian J Med Microbiol 2010;28:62-4.

Funding: None; Conflicts of Interest: None Stated.

How to cite this article: Bhansali VD, Kalane SU, Mandke H, Joe G. Rhizobium radiobacter - A rare organism causing central lineassociated bloodstream infection in a preterm neonate. Indian J Child Health. 2020; 7(10):418-420. 